\title{
Leishmaniasis and phlebotomine sand flies in Oman Sultanate
}

\author{
Jean-Antoine Rioux ${ }^{1, \dagger}$, Marina Gramiccia ${ }^{2}$, Nicole Léger $^{3}$, Philippe Desjeux ${ }^{4}$, and Jérôme Depaquit ${ }^{3,5,6, *}$ \\ ${ }^{1}$ Faculté de Médecine, Université Montpellier 1, 1 rue de l'Éencole de Médecine, 34000 Montpellier, France \\ 2 Department of Infectious Diseases, Unit of Vector-borne Diseases, Istituto Superiore di Sanità, Viale Regina Elena 299, \\ 00161 Rome, Italy \\ ${ }^{3}$ Université de Reims Champagne-Ardenne, EA7510, Université de Reims Champagne-Ardenne, Faculté de Pharmacie, \\ 51 rue Cognacq-Jay, 51096 Reims cedex, France \\ ${ }^{4}$ PATH OWH (formerly One World Health), A-9, Qutub Institutional area, USO Road, New Delhi 110067, India \\ 5 ANSES, USC Transmission Vectorielle et Épidémiosurveillance de Maladies Parasitaires (VECPAR), 51100 Reims, France \\ ${ }^{6}$ Laboratoire de Parasitologie, Pôle de Biologie, Centre Hospitalier Universitaire de Reims, 51100 Reims, France
}

Received 7 August 2020, Accepted 3 November 2020, Published online 27 November 2020

\begin{abstract}
There are few data on leishmaniases and sandflies in Oman Sultanate. We carried out an ecoepidemiological study in 1998 in the two main mountains of the country, the Sharqiyah and the Dhofar. This study allowed us to isolate and identify three Leishmania strains from patients exhibiting cutaneous leishmaniasis. The typing carried out by isoenzymatic study and by molecular biology were congruent: two strains of Leishmania donovani zymodeme (Z) MON-31 isolated in the Sharqiyah and one L. tropica ZROM102 (ZMON-39 variant for 4 isoenzymes) from the Dhofar. No strain was isolated from canids. The study of sandflies identified 14 species distributed in the genera Phlebotomus, Sergentomyia and Grassomyia: Ph. papatasi, Ph. bergeroti, Ph. duboscqi, Ph. alexandri, Ph. saevus, Ph. sergenti, Se. fallax, Se. baghdadis, Se. cincta, Se. christophersi, Se. clydei, Se. tiberiadis, Se. africana, and $G r$. dreyfussi. In Sharqiyah, the only candidate for the transmission of L. donovani was Ph. alexandri, but the low densities observed of this species do not argue in favor of any role. In Dhofar, Ph. sergenti is the most important proven vector of $L$. tropica, but $P h$. saevus, a locally much more abundant species, constitutes a good candidate for transmission.
\end{abstract}

Key words: Eco-epidemiology, Leishmania isolation and typing, Patients, Phlebotomine sandflies, Oman.

Résumé - Leishmanioses et phlébotomes au Sultanat d'Oman. Il existe peu de données sur les leishmanioses et les phlébotomes en Oman. Nous y avons mené en 1998 une étude éco-épidémiologique dans les deux principaux massifs montagneux du pays, la Sharqiyah et le Dhofar. Cette étude nous a permis d'isoler et d'identifier trois souches de Leishmania à partir de patients présentant des leishmanioses cutanées. Les typages menés par étude isoenzymatique et par biologie moléculaire ont été congruents : deux souches de Leishmania donovani ZMON-31 isolées dans la Sharqiyah et une de L. tropica ZROM102 (ZMON-39 variant pour 4 isoenzymes) originaire du Dhofar. Aucune souche n'a été isolée à partir de Canidés. L'étude des Phlébotomes a permis d'identifier 14 espèces réparties dans les genres Phlebotomus, Sergentomyia et Grassomyia : Ph. papatasi, Ph. bergeroti, Ph. duboscqi, Ph. alexandri, Ph. saevus, Ph. sergenti, Se. fallax, Se. baghdadis, Se. cincta, Se. christophersi, Se. clydei, Se. tiberiadis, Se. africana et Gr. dreyfussi. Dans la Sharqiyah, la seule espèce candidate à la transmission de L. donovani est $P h$. alexandri mais les faibles densités observées de cette espèce ne plaident pas en faveur d'un quelconque rôle. Dans le Dhofar, Ph. sergenti est le principal vecteur prouvé de L. tropica mais Ph. saevus, espèce localement bien plus abondante, constitue une bonne espèce candidate à la transmission.

\footnotetext{
*Corresponding author: jerome.depaquit@univ-reims.fr ${ }^{\dagger}$ in memoriam Prof Rioux passed away at the beginning of 2017 [29]. One month before his death, he met the last author. They analyzed together all the data and started writing this work. Feeling weakened, he asked the last author to finish writing this article in order to publish it in the journal Parasite.
}

\section{Introduction}

Leishmaniasis remains poorly documented in Oman Sultanate as well as the fauna of their vectors, Phlebotomine sandflies [5]. A few case reports are available in the literature of both visceral (VL) [6, 12, 21-23, 30, 63, 64] and cutaneous (CL) $[64,65,71]$ leishmaniases. However, to our knowledge, 


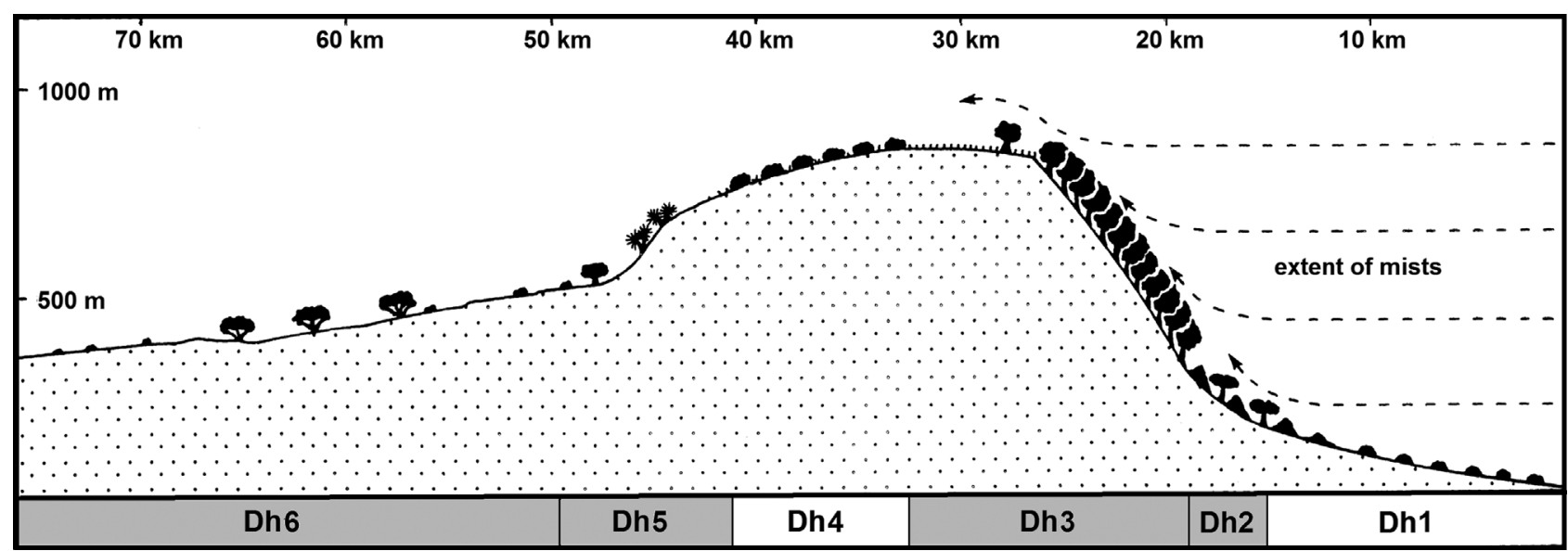

Figure 1. Diagram showing a cut of the Djebel Qara, in the vicinity of Salalah (Dhofar) after [46], modified. Dh1: shores with Avicennia marina (residual mangrove); Dh2: piedmont with Boscia arabica; Dh3: mountain flanks and humid escarpments with Anogeissus dhofarica and hilly plateaus with steppes and grasses; Dh4: arid plateau with Euphorbia balsamifera.; Dh5: scree and perarid reg desert with Boswellia sacra; Dh6: wadis and perarid cliffs with Acacia ethbaica and Dracaena serrulata. The sampled bioclimatic levels are indicated in grey.

no parasite has been cultured and typed according to gold standard methods (isoenzymes or PCR-RFLP or sequencing of targeted markers) except one strain of $L$. tropica isolated from a Pakistani patient continuously resident in Oman for the 18 months before parasite isolation [65]. No record of affected animals like dogs has been documented. The agents of VL belong to the L. donovani complex without identification at the specific level (L. donovani s. st. or L. infantum) [63]. A few studies have been carried out to identify the sandflies of the Sultanate [36].

Visceral leishmaniasis is confined principally to children in the Sharqiyah [50] and Dhofar [25] governorates. Between 1992 and 1995, the annual incidence rate of VL in Oman varied from 14 to 40 cases, but many children treated empirically for kala-azar are not reported [64]. The annual incidence rate is decreasing to 15-20 CL and 2-4 VL cases yearly [8].

The goal of the present study was to isolate and culture Leishmania strains in order to identify them from humans and wild or domestic canids, and to carry out an inventory of the Phlebotomine sandflies of the country in order to determine candidate(s) for Leishmania transmission according to the eco-epidemiological concept. This concept started in the 1950s and was applied in Mediterranean foci (France, Italy, Spain, Tunisia, Algeria, Morocco, Syria) and the Arabian peninsula (Yemen).

\section{Material and methods}

\section{Ethical approval}

The study (inclusion of patients, animals and captures of Phlebotomine sandflies) was carried out in 1998 in agreement with the World Health Organization, the Omani Ministry of Health, and the Omani Ministry of Agriculture. All laws and regulations were strictly followed. At that time, no ethics committee existed in Oman [7]. In all cases, patient records and information were anonymised and de-identified prior to analysis.

\section{Study sites}

We prospected the two main biogeographical regions of Oman from September 26 to October 26, 1998: Sharqiyah and Dhofar.

In the Sharqiyah region, analysis of places where CL and VL cases occurred was performed on selected farms in the Ibra alluvial basin. Houses were occupied by one to two families living mostly with some cows and herds of sheep and goats. The cows remained in the stable, while the herds were driven into the steppes and the surrounding hills. In order to complete the vector sampling, trapping with adhesive traps was carried out on the rockslides, cracks, holes and caves of the Ouadi Mouqal cliffs.

The Dhofar region was given special attention, not only because of the presence of VL and CL, but also its phyto and zoo-geographical originality (Afro-tropical elements, endemism) [26, 46]. The use of the transect method lead us to sample the different phyto-ecological climaxes, from Salalah to Herwouib, through the Qara and Qamar djebels, the Jejouel reg, the Wad Afaoul and the Wadi Herwouib (Figs. 1, 2 and 3). Among these climaxes, two were chosen because of their endemic richness: the slopes watered with Anogeissus and the thalwegs and wadi with Acacia, Boswellia and Dracaena.

\section{Phlebotomine sandflies sampling}

The trapping sites were selected according to both field observations (orography, geology, geomorphology, vegetation, human habitat) and information acquired prior to the field work: human cases of VL or CL, entomological and parasitological studies, and expert reports. Sampling was carried out by combining miniature CDC traps and sticky traps.

One to three CDC miniature light traps were installed in the previously selected biotopes: houses, stables, sheepfolds, caves, and various vegetation. They were placed at the end of the afternoon and picked up the next morning before sunrise. Sandflies were stored in $95 \%$ ethanol. 


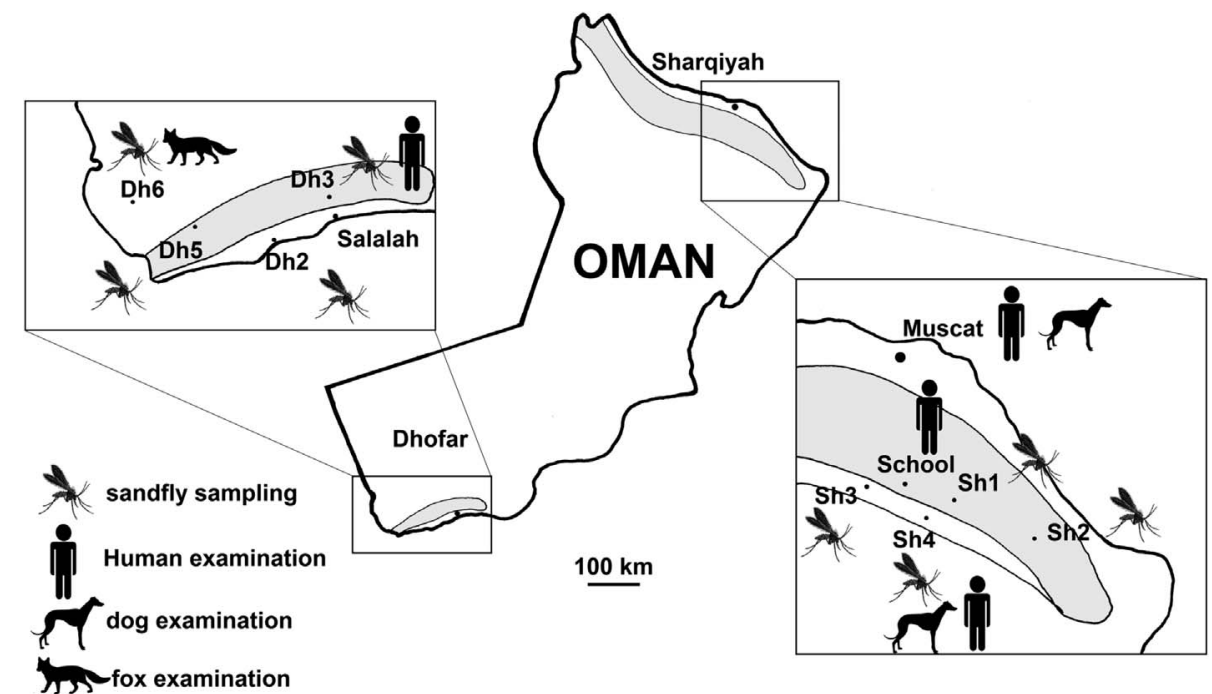

Figure 2. Map showing the sampling of phlebotomine sandflies, dogs, foxes and patients. Locations in the Sharqiyah are labelled Sh and those from the Dhofar are labelled Dh, in accordance with Figure 1.

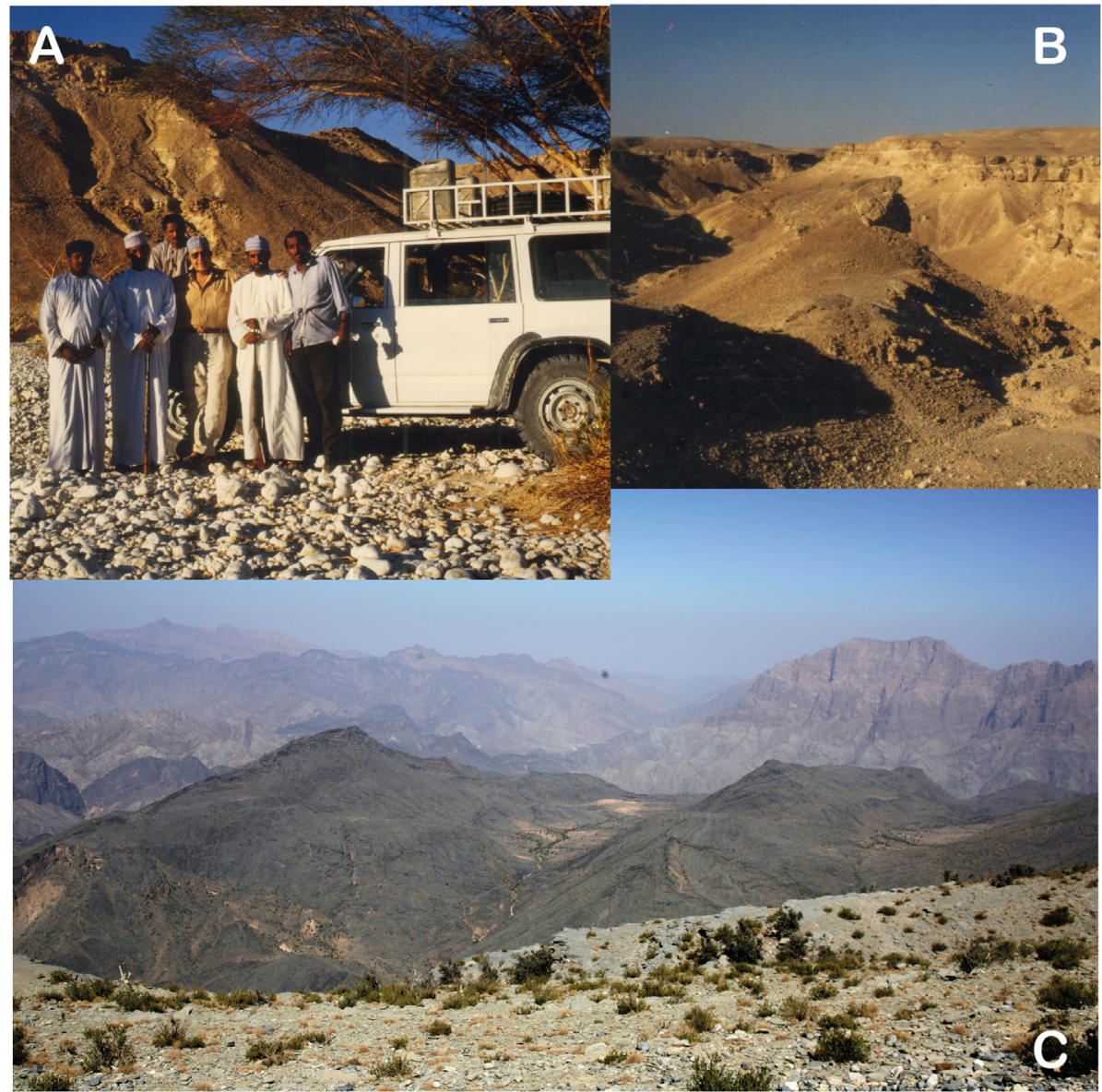

Figure 3. (A) Professor Rioux and the field team in the Dhofar; (B) Ouadi Herwouib in the Dhofar labelled Dh6 in accordance with Figure 1 where Ph. bergeroti, Ph. alexandri, Se. tiberiadis and Se. fallax are the most abundant species. (C) the Sharqiyah around the Ouadi. 
Table 1. Details about the places where sandflies, patients, dogs and fox have been sampled.

\begin{tabular}{|c|c|c|c|c|c|c|c|c|c|c|c|}
\hline $\begin{array}{l}\text { Symbol } \\
\text { (Fig. 1) }\end{array}$ & Collection & Location & Latitude & Longitude & Altitude & $\begin{array}{c}\text { Number } \\
\text { of }\end{array}$ & $\begin{array}{c}\text { Number } \\
\text { of CDC } \\
\text { traps }\end{array}$ & $\begin{array}{l}\text { Number } \\
\text { of patients } \\
\text { examinated }\end{array}$ & $\begin{array}{c}\text { Number of } \\
\text { Leishmania } \\
\text { strains } \\
\text { isolated }\end{array}$ & $\begin{array}{c}\text { Number of } \\
\text { dogs } \\
\text { examinated }\end{array}$ & $\begin{array}{l}\text { Number } \\
\text { of fox } \\
\text { examinated }\end{array}$ \\
\hline \multirow[t]{2}{*}{ Sh1 } & Sandflies & El Kederi farm & $22^{\circ} 47 \mathrm{~N}$ & $58^{\circ} 41 \mathrm{E}$ & 450 & 33 & 4 & & & & \\
\hline & & Batem & $22^{\circ} 49 \mathrm{~N}$ & $58^{\circ} 41 \mathrm{E}$ & 400 & 20 & 1 & & & & \\
\hline \multirow[t]{3}{*}{ Sh2 } & Sandflies & Hedna & $22^{\circ} 37 \mathrm{~N}$ & $59^{\circ} 06 \mathrm{E}$ & 400 & 31 & 4 & & & & \\
\hline & & Ouali gorges & $22^{\circ} 36 \mathrm{~N}$ & $59^{\circ} 05 \mathrm{E}$ & 600 & 101 & & & & & \\
\hline & & Ouali Mouqual & $22^{\circ} 36 \mathrm{~N}$ & $59^{\circ} 05 \mathrm{E}$ & 550 & 188 & & & & & \\
\hline $\mathrm{Sh} 3$ & $\begin{array}{l}\text { Sandflies, } \\
\text { patient }\end{array}$ & Al Rawdah & $22^{\circ} 53 \mathrm{~N}$ & $58^{\circ} 13 \mathrm{E}$ & 600 & 67 & 3 & 1 & 1 & & \\
\hline \multirow[t]{2}{*}{ Sh4 4} & Sandflies, dogs & Al Khanatar & $22^{\circ} 42 \mathrm{~N}$ & $58^{\circ} 32 \mathrm{E}$ & 400 & 87 & 5 & & & & \\
\hline & & Ibra & $22^{\circ} 43 \mathrm{~N}$ & $58^{\circ} 31 \mathrm{E}$ & & & & & & 9 & \\
\hline Mascate & Patients, dogs & Muscat & $23^{\circ} 32 \mathrm{~N}$ & $58^{\circ} 24 \mathrm{E}$ & & & & 1 & 1 & 4 & \\
\hline School & Patients, dogs & Kafaifa school & $22^{\circ} 53 \mathrm{~N}$ & $58^{\circ} 25 \mathrm{E}$ & & & & 238 & 0 & & \\
\hline \multirow[t]{2}{*}{$\mathrm{Dh} 2$} & Sandflies & $\begin{array}{l}\text { Djebel Al Qamar, } \\
\text { rocks }\end{array}$ & $16^{\circ} 55 \mathrm{~N}$ & $53^{\circ} 44 \mathrm{E}$ & 20 & 24 & & & & & \\
\hline & & Rocks & $16^{\circ} 89 \mathrm{~N}$ & $53^{\circ} 70 \mathrm{E}$ & 300 & 11 & & & & & \\
\hline \multirow[t]{5}{*}{ Dh3 } & $\begin{array}{l}\text { Sandflies, } \\
\text { patient }\end{array}$ & Djebel Qara, farm & $17^{\circ} 08 \mathrm{~N}$ & $54^{\circ} 00 \mathrm{E}$ & 600 & 23 & 3 & 1 & 1 & & \\
\hline & & Djebel Qara, house, farm & $17^{\circ} 07 \mathrm{~N}$ & $54^{\circ} 01 \mathrm{E}$ & 500 & 25 & 2 & & & & \\
\hline & & Djebel Qara, rocks & $17^{\circ} 06 \mathrm{~N}$ & $54^{\circ} 03 \mathrm{E}$ & 240 & 20 & & & & & \\
\hline & & Djebel Qara, rocks & $17^{\circ} 06 \mathrm{~N}$ & $54^{\circ} 03 \mathrm{E}$ & 240 & 30 & & & & & \\
\hline & & Djebel Qara & $17^{\circ} 14 \mathrm{~N}$ & $54^{\circ} 02 \mathrm{E}$ & 800 & & 2 & & & & \\
\hline \multirow[t]{2}{*}{ Dh5 } & Sandflies & Rocks & $16^{\circ} 57 \mathrm{~N}$ & $53^{\circ} 19 \mathrm{E}$ & 800 & 35 & & & & & \\
\hline & & Jejouel, village & $16^{\circ} 58 \mathrm{~N}$ & $53^{\circ} 13 \mathrm{E}$ & 800 & 25 & & & & & \\
\hline \multirow[t]{2}{*}{$\mathrm{Dh} 6$} & Sandflies, fox & $\begin{array}{l}\text { Ouadi Herwouib, } \\
\text { animal shelter }\end{array}$ & $17^{\circ} 05 \mathrm{~N}$ & $52^{\circ} 59 \mathrm{E}$ & 600 & 61 & 5 & & & & \\
\hline & & Ouadi Herwouib, rocks & $17^{\circ} 04 \mathrm{~N}$ & $52^{\circ} 59 \mathrm{E}$ & 600 & 34 & & & & & 1 \\
\hline Total & & & & & & 815 & 29 & 241 & 3 & 13 & 1 \\
\hline
\end{tabular}

We express the relative frequencies of species by reporting the number of sandflies caught per "night/trap" $(\mathrm{s} / \mathrm{n} / \mathrm{t})$.

Sticky traps were made with white paper sheets $\left(20 \times 20 \mathrm{~cm}\right.$ for a double-sided active surface of $\left.800 \mathrm{~cm}^{2}\right)$ impregnated with castor oil. They are placed in the crevices of walls or rocks, at the opening of burrows, in stables, sheepfolds, and henhouses. The number of traps deposited is shown in Table 1. Sandflies are collected from the trap with a little brush and stored in $100 \%$ ethanol. After their identification, results were expressed as the number of specimens (males, females, total) per species and per square meter of trap (relative densities). The grouping of the stations allowed for calculation of the densities by climax [58, 59].

During the present field work, 21 stations were sampled in 18 localities using CDC traps (29 nights/traps) and/or the sticky trap (815 traps representing a total interception area of $65.2 \mathrm{~m}^{2}$ ). These stations were grouped by locality and/or biotope (Table 1).

Most of the sandflies were processed to be mounted in toto according to the following protocol. Soft tissues were lysed in a bath of $\mathrm{KOH} 10 \%(12 \mathrm{~h})$, then washed four times in distilled water, cleared in Marc-André solution (12 h), and mounted individually between microscope slide and cover slide in Canada Balsam for species identification, after dehydration in successive alcoholic baths then clove oil.

A few specimens were processed individually to allow molecular biology processing $[16,19]$. They were mounted in chloral gum directly after the Marc-André solution step.

Visual analysis of the specimens was performed by means of a BX61 microscope (Olympus, Japan). Measurements and counts were made using Stream Motion software (Olympus, Japan) and a video camera connected to the microscope.

The identifications were made thanks to the original descriptions of each of the species encountered, as well as available keys and papers $[1,10,18,39,41-43]$.

\section{Vertebrate hosts sampling; Leishmania detection, isolation and identification}

\section{Human}

\section{Human leishmaniasis}

Among the human leishmaniasis cases reported in Oman, only cutaneous forms were observed. All patients were hospitalised in Muscat and Ibra provinces (in Sharqiyah region) and Salalah province (in Dhofar region). Samples were biopsied by Arouette's bistoury (punch biopsy of single use) under local anaesthesia of lidocaine $\left(\right.$ Xylocaine $\left.^{\circledR}\right)$. Samples were obtained by fine scissors or hooked pliers. After crushing the samples in Potter mortar in a sterile solution of $\mathrm{NaCl}(0.9 \%)$ plus penicillin $\mathrm{G}(200,000 \mathrm{u} / \mathrm{mL})$, cultures were initiated on NNN medium (4 tubes per sample), with three drops of sterilised urine and a few drops of heart/brain solution, and incubated at $24{ }^{\circ} \mathrm{C}\left(23^{\circ}-26{ }^{\circ} \mathrm{C}\right)$. Control was performed 5 days later and a subculture carried out every 8 days. Cultures were considered sterile after four subcultures.

Simultaneously, crushing on slides was performed using new cutaneous samples. Slides were fixed by methanol and stained by Giemsa; therefore, they were examined by direct microscopical examinations using $50 \times$ oil immersion objective. 
Based on the leishmanin skin test method, the survey included a school population living close to Ibra. The L. major antigen, prepared by the Istituto Superiore di Sanità of Rome (Italy), was injected intradermally by Dermo-jet. Reactions were analysed $48 \mathrm{~h}$ later. The criterion for positivity was a papule of $5 \mathrm{~mm}$ diameter or more. Traditional leishmanin antigens react positively in most CL cases of the "Old World", regardless of the Leishmania species.

\section{Animal leishmaniases}

We mainly focused on domestic canids (dogs) and wild canids (foxes). Animals were slaughtered under the control of the police services. The necropsies (one fox and $5 \mathrm{dogs}$ ) were carried out in veterinary centres (dogs) or in the field (foxes). Spleen, liver and bone marrow were targeted. Giemsa stain smears and cultures on NNN medium were performed according to the protocol detailed above for human leishmaniasis cases.

\section{Leishmania species identification}

Isolated Leishmania strains were characterised by Multi Locus Enzyme Electrophoresis (MLLE) and confirmed by molecular identification. The identifications were performed at the Leishmania Identification Centre of the Unit of Vector-borne Diseases of the Istituto Superiore di Sanità of Rome (Italy).

\section{MLLE isoenzymatic identification}

Leishmania strains isolated in the present study were typed by iso-enzyme analysis on starch-gel electrophoresis [60] of 15 enzymatic systems: malate dehydrogenase (MDH1), isocitrate dehydrogenase (ICD), phosphoglucomutase (PGM), fumarase hydratase (FH), 6-phosphogluconate dehydrogenase (PGD), glucose-6-phosphate dehydrogenase (G6PD), diaphorase (DIA1), glutamate dehydrogenase (GLUD), purine nucleoside phosphatase (NP1), purine nucleoside phosphorylase (NP2), glutamate-oxaloacetate transaminase (GOT1, GOT2), mannose phosphate isomerase (MPI), glucose phosphate isomerase (GPI), and malic enzyme (ME). The Omani Leishmania strains were typed using WHO reference strains of $L$. infantum zymodeme (Z) MON1 (MHOM/TN/80/IPT1), L. donovani ZMON2 (MHOM/IN/80/DD8), L. tropica ZMON60 (MHOM/SU/74/ K27) and L. major ZMON4 (MHOM/SU/73/5-ASKH). Furthermore, several strains of Leishmania species/zymodemes previously isolated in Oman's neighbouring countries were also used as references. When a new zymodeme was identified, this was provisionally named a "variant" (var) of the most similar classified MON zymodeme, and the electrophoretic mobility (me) of the variant enzyme(s) was reported. The isoenzymes me were identified according to both $\mathrm{Z}$ Montpellier (MON) and $\mathrm{Z}$ Rome (ROM) nomenclatures.

\section{Molecular identification}

The isolated Leishmania strains were typed by PCR-RFLP analysis targeting ITS-1 (internal transcribed spacer-1) [62] and Heat Shock Protein (HSP70) [70] according to the protocol detailed in the original techniques.

\section{Results}

\section{Phlebotomine sandflies}

During the present study, a total of 707 sandflies were captured by the technique of sticky traps. Of these, 331 were trapped in the Sharqiyah, with an overall density of 7.85 sandflies $/ \mathrm{m}^{2}$ trap and 376 traps in Dhofar, at an average density of 16.32 sandflies $/ \mathrm{m}^{2}$ trap (Table 2). Using the CDC miniature light traps, a total of 360 sandflies were captured: 115 sandflies in the Sharqiyah (with an average of 6.76 sandflies/night/trap) and 245 in the Dhofar (with an average of 20 sandflies/night/ trap) (Table 3).

The species we caught belonged to the genera Phlebotomus, Sergentomyia and Grassomyia: Phlebotomus (Phlebotomus) papatasi (Scopoli, 1786), Ph. (Phl.) bergeroti Parrot, 1934, Ph. (Phl.) duboscqi Neveu-Lemaire, 1906, Ph. (Paraphlebotomus) alexandri Sinton, 1928, Ph. (Par.) saevus Parrot \& Martin, 1939, Ph. (Par.) sergenti Parrot, 1917, Sergentomyia (Sergentomyia) fallax (Parrot, 1921), Se. (Ser.) baghdadis (Adler \& Theodor, 1929), Se. (Ser.) cincta (Parrot \& Martin, 1944), Se. (Sin.) christophersi (Sinton, 1927), Se. (Sin.) clydei (Sinton, 1928), Se. (Sin.) tiberiadis (Adler, Theodor \& Lourie, 1930), Se. (Parrotomyia) africana (Newstead, 1912), and Grassomyia dreyfussi (Parrot, 1933). A few specimens were not identified (damaged) or identified to a subgeneric level (low mounting quality).

\section{Comments on sandfly species} [24]

The terminology used in this paper is that recently proposed

\section{Phlebotomus (Phlebotomus) papatasi (Scopoli, 1786)}

The male is characterised by the presence of two spines at the end of the surstyle, by a group of more than ten big setae at the distal part of the gonocoxite, by the upper part of the paramere longer than the other ones and covered with setae along its full length. The ascoids are relatively short and never reach the next articulation.

The female is identified by its annealed spermathecae with sessile head wrapped in a cloud. Its pharyngeal armature presents teeth with, at the anterior part, many comb-like ones. Ascoids never reach the next articulation.

The distribution of this major vector of L. major [34] is very large, from Bangladesh to Morocco and from Crimea to Sudan. Limited to the North of the Sahara in West Africa, the species is most southern in East Africa. In Oman, the species is absent in the Dhofar, but dominates in the Sharqiyah. It was previously recorded in the Wahiba sands of the Sultanate [36].

\section{Phlebotomus (Phlebotomus) bergeroti Parrot, 1934}

The male is characterised by the presence of two spines at the end of the surstyle. The gonocoxite has a subapical tuft not exceeding ten setae. The upper part of the paramere is slightly longer than the other ones and covered with bristles in its distal half only. 
Table 2. Captures made using sticky traps in locations mentioned in Figures 1 and $2 . \hat{\jmath}=$ males, $q=$ females, $\hat{\jmath}+q=$ males and females, $\mathrm{s} / \mathrm{m}^{2}=$ density of sandflies (per $\mathrm{m}^{2}$ of sticky paper).

\begin{tabular}{|c|c|c|c|c|c|c|c|c|c|c|c|c|c|c|c|c|c|c|c|c|c|c|c|c|}
\hline \multirow{2}{*}{$\begin{array}{l}\text { Location } \\
\text { Species }\end{array}$} & \multicolumn{4}{|c|}{ Sharqiyah } & \multicolumn{4}{|c|}{ Dh2 } & \multicolumn{4}{|c|}{ Dh3 } & \multicolumn{4}{|c|}{ Dh5 } & \multicolumn{4}{|c|}{ Dh6 } & \multicolumn{4}{|c|}{ Total Dhofar } \\
\hline & $\hat{\jmath}$ & q & $\hat{o}+q$ & $\mathrm{~s} / \mathrm{m}^{2}$ & $\hat{\jmath}$ & q & $\hat{\jmath}+q$ & $\mathrm{~s} / \mathrm{m}^{2}$ & $\hat{\jmath}$ & q & $\hat{o}+q$ & $\mathrm{~s} / \mathrm{m}^{2}$ & $\hat{0}$ & q & $\hat{o}+q$ & $\mathrm{~s} / \mathrm{m}^{2}$ & $\hat{\jmath}$ & q & $\hat{0}+q$ & $\mathrm{~s} / \mathrm{m}^{2}$ & $\hat{\jmath}$ & q & $\hat{o}+q$ & $\mathrm{~s} / \mathrm{m}^{2}$ \\
\hline $\begin{array}{c}\text { Phlebotomus } \\
\text { papatasi }\end{array}$ & 35 & 14 & 49 & 1.16 & & & & & & & & & & & & & & & & & & & & \\
\hline $\begin{array}{c}\text { Phlebotomus } \\
\text { bergeroti }\end{array}$ & 2 & 2 & 4 & 0.09 & & & & & & & & & & & & & 45 & 4 & 49 & 0.84 & 45 & 4 & 49 & 2.13 \\
\hline $\begin{array}{l}\text { Phlebotomus } \\
\text { duboscqi }\end{array}$ & & 2 & 2 & 0.05 & & & & & & & & & & & & & & & & & & & & \\
\hline $\begin{array}{l}\text { Phlebotomus } \\
\text { alexandri }\end{array}$ & 3 & & 3 & 0.07 & & & & & & & & & & & & & 31 & 4 & 35 & 0.60 & 31 & 4 & 35 & 1.52 \\
\hline $\begin{array}{l}\text { Phlebotomus } \\
\text { saevus }\end{array}$ & & & & & 4 & & 4 & 1.43 & & 4 & 4 & 0.51 & 2 & & 2 & 0.42 & 1 & 1 & 2 & 0.03 & 7 & 5 & 12 & 0.52 \\
\hline $\begin{array}{l}\text { Phlebotomus } \\
\text { sergenti }\end{array}$ & 8 & & 8 & 0.19 & & & & & & & & & & & & & 7 & 3 & 10 & 0.17 & 7 & 3 & 10 & 0.43 \\
\hline $\begin{array}{r}\text { Grassomyia } \\
\text { dreyfussi }\end{array}$ & & 2 & 2 & 0.05 & & 1 & 1 & 0.36 & & & & & & & & & & & & & & 1 & 1 & 0.04 \\
\hline $\begin{array}{l}\text { Sergentomyia } \\
\quad \text { fallax }\end{array}$ & 4 & 4 & 8 & 0.19 & 27 & 30 & 57 & 20.36 & & & & & & & & & 22 & 50 & 72 & 1.23 & 49 & 80 & 129 & 5.60 \\
\hline $\begin{array}{l}\text { Sergentomyia } \\
\quad \text { cincta }\end{array}$ & 29 & 9 & 38 & 0.90 & & & & & & & & & & & & & 5 & 2 & 7 & 0.12 & 5 & 2 & 7 & 0.30 \\
\hline $\begin{array}{l}\text { Sergentomyia } \\
\text { christophersi }\end{array}$ & 67 & 39 & 106 & 2.51 & 1 & 8 & 9 & 3.21 & & 3 & 3 & 0.38 & & & & & 8 & 6 & 14 & 0.24 & 9 & 17 & 26 & 1.13 \\
\hline $\begin{array}{l}\text { Sergentomyia } \\
\quad \text { clydei }\end{array}$ & 5 & 4 & 9 & 0.21 & & & & & & & & & & & & & & & & & & & & \\
\hline $\begin{array}{l}\text { Sergentomyia } \\
\text { tiberiadis }\end{array}$ & 50 & 21 & 71 & 1.68 & 2 & 8 & 10 & 3.57 & 1 & 6 & 7 & 0.89 & 1 & & 1 & 0.21 & 52 & 26 & 78 & 1.34 & 56 & 40 & 96 & 4.17 \\
\hline $\begin{array}{l}\text { Sergentomyia } \\
\text { africana }\end{array}$ & & & & & & & & & & & & & & & & & & & & & & & & \\
\hline $\begin{array}{c}\text { Sergentomyia } \\
\text { baghdadis }\end{array}$ & 13 & 12 & 25 & 0.59 & & & & & & & & & & & & & & & & & & & & \\
\hline $\begin{array}{l}\text { Sergentomyia } \\
\quad \text { (Sintonius) sp. }\end{array}$ & 1 & 2 & 3 & 0.07 & 1 & & 1 & 0.36 & & & & & & & & & & & & & 1 & & 1 & 0.04 \\
\hline Undetermined & 3 & & 3 & 0.07 & 1 & & 1 & 0.36 & & 1 & 1 & 0.13 & & & & & 4 & 4 & 8 & 0.14 & 5 & 5 & 10 & 0.43 \\
\hline Total & 220 & 111 & 331 & 7.85 & 36 & 47 & 83 & 29.64 & 1 & 14 & 15 & 1.91 & 3 & 0 & 3 & 0.63 & 175 & 100 & 275 & 4.71 & 215 & 161 & 376 & 16.32 \\
\hline
\end{tabular}

The female is identified by its annealed spermathecae with sessile head, by a pharynx armed with teeth without spines or denticles on the posterior part and by the presence of anterior bilateral teeth. Ascoids reach or exceed the next articulation.

The distribution of Ph. bergeroti is wide: from Morocco to Iran. Its southern limit is the Sudan. In Oman, it is a scarce species in the Sharqiyah and the semi-arid zone of Dhofar, but it becomes abundant in the perarid part of the latter region. The strong anthropophily of $P h$. bergeroti, and its abundance in certain perarid areas $[2,44]$ are arguments in favor of a significant vector role for L. major in the extreme deserts of Africa and the Arabian peninsula.

\section{Phlebotomus (Phlebotomus) duboscqi Neveu-Lemaire, 1906}

The male is characterised by the presence of four to seven spines at the end of the surstyle. The gonocoxite has about ten setae in its distal half, and usually two ones in its proximal part. The upper part of the paramere is slightly shorter than the other ones and is covered with setae throughout its length. The female is identified by its annealed spermathecae with sessile head. Its pharyngeal armature does not exhibit comb-like or lateral teeth. Ascoids sometimes reach the next articulation.

Its distribution is south of the Sahara to the Equator in Africa, and extends into the Arabian Peninsula. In Oman, the species is absent from Dhofar and seems rare in Sharqiyah, where we captured only two specimens.

This species constitutes in some foci a good alternative to L. major transmission by $P h$. papatasi [15].

\section{Phlebotomus (Paraphlebotomus) sergenti Parrot, 1917}

The male has, like all Paraphlebotomus, a basal lobe on gonocoxite and its gonostyle carries four spines. However, it is easily identified by the curved shape of this basal lobe and by the brush of some setae that it carries, by its hooked parameral sheath, and by its globular gonostyle.

The female of $P h$. sergenti is very difficult to separate from that of Ph. saevus. In Ph. sergenti, the well-developed pharyngeal armature contains strong elongated teeth, which are less numerous than in $P h$. saevus. The geographical distribution of Ph. sergenti is very wide: from the Canary Islands to India and from Ukraine to Kenya. However, the diagnosis is delicate with an affine species $P h$. similis whose distribution area that was initially thought to be limited to the North-east of the Mediterranean basin [17] is finally greater with a large area of sympatry in the Middle-East [47]. In Oman, we identified $P h$. sergenti in small numbers (10 males) and still in wild sites (cavities and rocky chaos) in the Sharqiyah (Wadi Mouqal, at altitudes ranging from 550 to $600 \mathrm{~m}$ ) and in the Dhofar (Wadi Herwouib, altitude $600 \mathrm{~m}$ ). This species had already been 
Table 3. Captures made using CDC miniature light traps in locations mentioned in Figures 1 and $2 . \hat{\jmath}=$ males, $q=$ females, $\hat{\jmath}+q=$ males and females, $\mathrm{s} / \mathrm{n} / \mathrm{t}=$ number of sandflies per night per trap.

\begin{tabular}{|c|c|c|c|c|c|c|c|c|c|c|c|c|c|c|c|c|}
\hline \multirow{2}{*}{$\begin{array}{l}\text { Location } \\
\text { Species }\end{array}$} & \multicolumn{4}{|c|}{ Sharqiyah } & \multicolumn{4}{|c|}{ Dh3 } & \multicolumn{4}{|c|}{ Dh6 } & \multicolumn{4}{|c|}{ Total Dhofar } \\
\hline & $\hat{0}$ & q & $\hat{0}+q$ & $\mathrm{~s} / \mathrm{n} / \mathrm{t}$ & $\hat{0}$ & q & $\hat{0}+q$ & $\mathrm{~s} / \mathrm{n} / \mathrm{t}$ & $\hat{\jmath}$ & $q$ & $\hat{\jmath}+q$ & $\mathrm{~s} / \mathrm{n} / \mathrm{t}$ & $\hat{0}$ & q & $\hat{0}+q$ & $\mathrm{~s} / \mathrm{n} / \mathrm{t}$ \\
\hline Phlebotomus papatasi & 3 & 13 & 16 & 0.94 & & & & & & & & & & & & \\
\hline $\begin{array}{l}\text { Phlebotomus bergeroti } \\
\text { Phlebotomus duboscai }\end{array}$ & 1 & 4 & 5 & 0.29 & 1 & & 1 & 0.14 & 57 & 27 & 84 & 16.8 & 58 & 27 & 85 & 7.08 \\
\hline $\begin{array}{l}\text { Phlebotomus duboscqi } \\
\text { Phlebotomus alexandri }\end{array}$ & & & & & & & & & 15 & 16 & 31 & 6.2 & 15 & 16 & 31 & 2.58 \\
\hline Phlebotomus saevus & & & & & 34 & 18 & 52 & 7.43 & 1 & 2 & 3 & 0.6 & 35 & 20 & 55 & 4.58 \\
\hline $\begin{array}{l}\text { Phlebotomus sergenti } \\
\text { Grassomyia dreyfussi }\end{array}$ & & & & & & & & & & & & & & & & \\
\hline Sergentomyia fallax & & & & & 4 & 2 & 6 & 0.86 & 9 & 22 & 31 & 6.2 & 13 & 24 & 37 & 3.08 \\
\hline Sergentomyia cincta & & 2 & 2 & 0.12 & 1 & & 1 & 0.14 & & & & & 1 & & 1 & 0.08 \\
\hline Sergentomyia christophersi & 4 & 5 & 9 & 0.53 & 4 & 2 & 6 & 0.86 & 5 & 6 & 11 & 2.2 & 9 & 8 & 17 & 1.42 \\
\hline Sergentomyia clydei & 3 & 1 & 4 & 0.24 & 1 & & 1 & 0.14 & & & & & 1 & & 1 & 0.08 \\
\hline Sergentomyia tiberiadis & & 1 & 1 & 0.06 & 6 & 2 & 8 & 1.14 & 3 & 3 & 6 & 1.2 & 9 & 5 & 14 & 1.17 \\
\hline Sergentomyia africana & & & & & & & & & & 2 & 2 & 0.4 & & 2 & 2 & 0.17 \\
\hline $\begin{array}{l}\text { Sergentomyia baghdadis } \\
\text { Sergentomyia (Sintonius) sp. }\end{array}$ & 25 & 53 & 78 & 4.59 & & & & & & & & & & & & \\
\hline Total & 36 & 79 & 115 & 6.76 & 52 & 24 & 76 & 10.9 & 90 & 79 & 169 & 33.8 & 142 & 103 & 245 & 20 \\
\hline
\end{tabular}

captured in the north-east of the country, near the village of Awabi [61].

Ph. sergenti is the most important proven vector of L. tropica $[4,28]$.

\section{Phlebotomus (Paraphlebotomus) saevus Parrot \& Martin, 1939}

The male of $P h$. saevus has a straight, non-hooked parameral sheath, a large basal lobe of the gonocoxite, with a weakly dilated distal portion carrying many long and slightly curved setae.

The Ph. saevus female is difficult to distinguish from that of $P h$. sergenti. Its pharyngeal armature is well developed and contains more teeth than those of Ph. sergenti (Fig. 4).

$P h$. saevus has a distribution including East Africa and Arabia. In Oman, this is its first record. We caught $P h$. saevus only in Dhofar (Djebel Quara), at the Dh3 capture site, an isolated farm where a female patient with leishmaniasis caused by L. tropica (LCO 4) lived.

Ph. saevus is a vector suspected of transmitting L. tropica in households where $P h$. sergenti is absent, like in Kenya [45] or Yemen [14].

\section{Phlebotomus (Paraphlebotomus) alexandri Sinton, 1928}

The male and female are easily identifiable thanks to their short first flagellomere (= AIII).

Moreover, in the male, there is a short basal lobe of the gonocoxite, with a spherical head, provided with radiant, generally rectilinear setae. The apical spine of the style is inserted on a long process, far from the subapical spine.

The female exhibits a pharyngeal armature of rectangular overall appearance without anterior extension, consisting of strongly chitinised, spiniform scales forming a thick network.

$P h$. alexandri occupies a vast geographical area: from Morocco to Mongolia down to Sudan. In Oman, Ph. alexandri is a fairly abundant Phlebotomus, especially in Dhofar. Here, $P h$. alexandri is mainly found in the desert zone at Boswellia
(Incense Tree), and more particularly in bottom of the Wadi (Herwouib).

With the exception of the isolation of $L$. donovani in China [27], the role of $P h$. alexandri as a vector is still under discussion. Its low abundance in the prospected areas of the Sharqiyah cannot yet explain its potential role in the transmission of L. donovani.

\section{Grassomyia dreyfussi (Parrot, 1933)}

This species is distinguished from other Oman species by the absence, in both sexes, of ascoids on the first flagellomere, which is a characteristic of the genus Grassomyia. Moreover, both male and female harbour strong spines on each femur (pro- and meso- and metafemur).

The female is recognised by the very characteristic pattern of her spermathecae, in capsule of opium poppy.

The distribution of Gr. dreyfussi extends from Morocco to Iran and goes down to Kenya. It has recently been recorded in the Arabian Peninsula [20]. Its record in Oman is not surprising in this context. In the Sultanate, we have captured very rare specimens in the Sharqiyah and Dhofar.

Its role in the transmission of a Leishmania has never been mentioned.

\section{Sergentomyia (Sergentomyia) fallax (Parrot, 1921)}

The male genitalia has a long and narrow gonostyle with a non-deciduous silk implanted very distally.

The female has a large pharynx with a well-developed armature consisting with monomorphic teeth forming a heartshaped pattern. The cibarium is armed with 15-23 pointed teeth, equal or sub-equal, arranged in an arch. The sclerotised area (= pigment patch) is oval.

The distribution of Se. fallax is wide. It extends from the Canary Islands and Morocco to Pakistan, covers the Arabian Peninsula and remains north of the Sahara. In Oman, Se. fallax is abundant in the Dhofar, while it is rather rare in the Sharqiyah. 
The role of this species has never been mentioned in the transmission of a Leishmania, despite its vicariant Se. dubia being a possible vector of $L$. infantum in Senegal [68].

\section{Se. (Ser.) cincta (Parrot \& Martin, 1944)}

This species belongs to the "Fallax group". The male cannot be distinguished from those of Se. antennata. The female of Se. cincta exhibits fewer cibarial teeth $(<20)$ than Se. antennata $(>22)$.

Se. cincta is mainly distributed throughout eastern Africa, but has also been reported in West Africa [1, 67, 69]. It was recently found in Cameroon [69]. Taking into consideration the number of cibarial teeth as a valid specific character, we identified the female specimens of Oman as Se. cincta and associated males, pending revision of this group, using molecular tools to check whether $S e$. cincta is individualised from Se. antennata.

This is the first record of Se. cincta in the Arabian Peninsula. In Oman, we recorded it mostly in the Sharqiyah, and a few specimens in the Dhofar.

\section{Se. (Sintonius) christophersi (Sinton, 1927)}

As a member of the subgenus Sintonius, the male exhibits a pointed parameral sheath, whereas the female has annealed spermathecae, a common character in the genus Phlebotomus but an original character in the genus Sergentomyia, shared only by the members of the subgenus Trouilletomyia [55].

The identification of the male is based on a few teeth (3-7) of the cibarial armature and the existence of a row of a few vertical teeth. Similarly, the female exhibits a few cibarial teeth (2-5) and a few anterior vertical teeth (4-6) arranged along a line.

The distribution area of Se. christophersi is wide: from Morocco to India, including Cameroon [69] and the Arabian Peninsula [20, 42]. In Oman, we found Se. christophersi both in the Sharqiyah and in the Dhofar.

\section{Se. (Sin.) clydei (Sinton, 1928)}

As a member of the subgenus Sintonius, the male exhibits a pointed parameral sheath, whereas the female has annealed spermathecae.

The identification of the male is based on the presence of 16-35 small cibarial teeth. The female exhibits a row counting $10-15$ cibarial teeth and a row of vertical teeth in variable number (from 4 to about 20) [19].

The distribution of $\mathrm{Se}$. clydei is wide and was recently revised [19]: from Senegal to Afghanistan, through the Arabian Peninsula and the Seychelles.

In Oman, we recorded a limited number of specimens, more in in the Sharqiyah than in the Dhofar.

Se. clydei is a sandfly feeding on humans as well as on reptiles [1, 68] but no Leishmania vectorial role has been demonstrated for this species.

\section{Se. (Sin.) tiberiadis (Adler, Theodor\& Lourie, 1930)}

As a member of the subgenus Sintonius, the male exhibits a pointed parameral sheath, whereas the female has annealed spermathecae.
The identification of the male is based on the presence of one row of 10-15 cibarial teeth, the median ones smaller than the lateral ones and 6-10 anterior vertical teeth. The female exhibits one row of 10-20 cibarial teeth, the median ones smaller than the lateral ones and two anterior rows of vertical teeth.

Se. tiberiadis is a species from the Middle East, including the Arabian Peninsula. It has never been involved in the transmission of Leishmania. It was previously recorded in the Wahiba sands [36].

\section{Se. (Parrotomyia) africana (Newstead, 1912)}

The female has a well-developed palisade-like cibarial armature of 55-80 teeth and smooth elongated capsule-like spermathecae typical of the subgenus Parrotomyia.

The male shows a cibarial armature of 20-35 teeth, palisade-like.

Se. africana is a member of a species complex called the Africana group, which requires revision by molecular tools as some identifications refer to the group rather than to the species sensu stricto. Its distribution area is wide. It includes Africa and the Middle-East, including the Arabian Peninsula.

This species has never been reported to be involved in the transmission of Leishmania.

\section{Se. (Par.) baghdadis (Adler \& Theodor, 1929)}

The male can be identified thanks to its cibarium with angle-shaped notch and 14-16 teeth. The identification is easy thanks to the deep notch on the cibarium, also exhibiting about 30 teeth (Fig. 4).

Its distribution is limited to a zone ranging from Iraq to India). The record in Oman is the first in the Arabian Peninsula. We recorded it only in the Sharqiyah, not in the Dhofar. It has never been suspected of transmitting human Leishmania.

\section{Leishmaniases and Leishmania species identification}

\section{Skin tests}

A total of 213 students (114 boys and 99 girls) from the school of Kafaifa (Ibra province) underwent skin tests. Among them, $17(8 \%)$ were positive. They exhibited an erythematous and pruritic papule of 1 or more $\mathrm{cm}$ in diameter. Girls were more susceptible to the disease $(13.3 \%)$ than boys $(10.1 \%)$. A low positivity rate seems to be due to a weak interaction between the young population and the Leishmania parasite in this focus (20 km from Ibra). It could be related to low density of sandfly vectors or their weak anthropophilia.

\section{Human CL case reports, sampling and cultures}

Four suspected human CL cases were observed, and 3 Leishmania strains were cultured and identified.

Case LCO 1:

Female, 17 years old, from the Muscat area (Sharqiyah region). Lesion on the right leg, beginning two years before. The CL diagnosis was confirmed by the presence of amastigotes in the lesion by microscopical examination. Treatment 

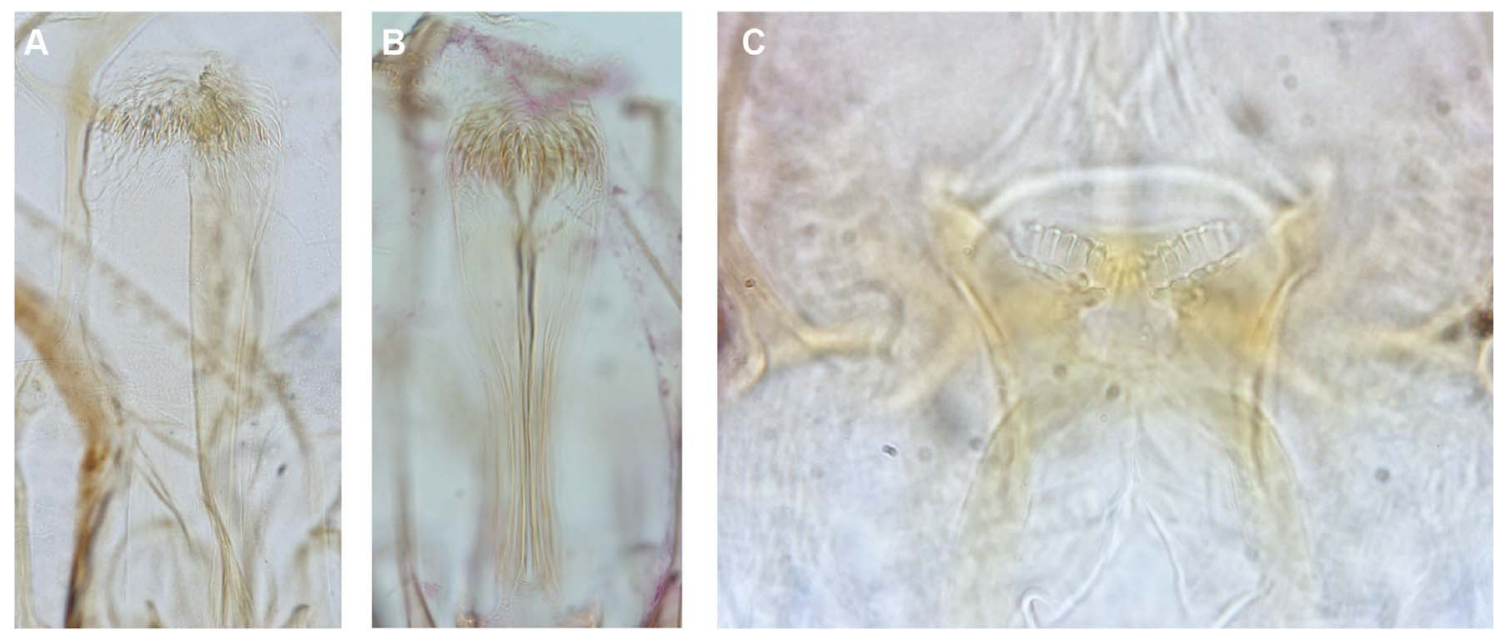

Figure 4. Pharynx of Ph. saevus (A), Ph. sergenti (B) and cibarium of Se. baghdadis (C).

by intramuscular sodium stibogluconate $\left(\right.$ Pentostam $\left.^{\circledR}\right)$. Improvement but relapse. New hospitalisation for skin graft. Currently pretibial lesion: round-shaped ulcer of $4 \mathrm{~cm}$ diameter with a red/purplish elevated border and necrotic surface. Intralesional treatment by sodium stibogluconate $\left(\right.$ Pentostam $\left.^{\circledR}\right)$. In 1998, on September 28, biopsy under local anaesthesia. Direct examination: negative, in vitro culture on $\mathrm{NNN}$ medium: positive at the 2nd subculture. Strain MHOM/OM/98/IBM103-ISS1783. MLLE identification: L. donovani ZMON-31 (= ZROM-24), L. donovani species identification was confirmed by molecular analyses.

Case LCO 2:

Female, 35 years old, living in Rowda (Ibra province, Sharqiyah region). Ulcero-scabby lesion on the left cheekbone, $3 \mathrm{~cm}$ in diameter with ulcerated centre and with an elevated and infiltrated border of 3-4 cm. In 1998, on September 16, consultation at Ibra hospital. CL diagnosis confirmed parasitologically by Giemsa stained smear. Local cryotherapy (pregnant woman). In 1998, on October 4, biopsy (Fig. 5). Direct microscopical examination of cutaneous smear and in vitro culture on NNN medium: positive. Strain MHOM/OM/98/IBM-104ISS1790. MLLE identification: L. donovani ZMON-31 (= ZROM-24), L. donovani species identification was confirmed by molecular analyses.

Case LCO 3:

Boy, 12 years old, observed at Kafaïfa school, $20 \mathrm{~km}$ North of Ibra (Sharqiyah region). In the middle of the forehead, scabby lesion of $1 \mathrm{~cm}$ diameter, initiated 3 months before. Leishmanin skin test positive $(1.5 \mathrm{~cm})$. Cutaneous biopsy: direct microscopical examination and in vitro culture in NNN medium: negative.

Case LCO 4:

Girl, 4 years old, living in Ghadow on the southern slopes of Djebel Qara (Dhofar region), altitude: $500 \mathrm{~m}$. The disease began 7 months before, by an erythematous lesion at the top of the nose. Treatment by intramuscular sodium stibogluconate (Pentostam ${ }^{\circledR}, 10$ injections) was initiated on September 9. Examination at Salalah hospital on October 21: red and purplish infiltrated lesion $(2 \mathrm{~cm})$ at the top of the nose. Sample obtained by scraping with curette. Direct microscopical examination

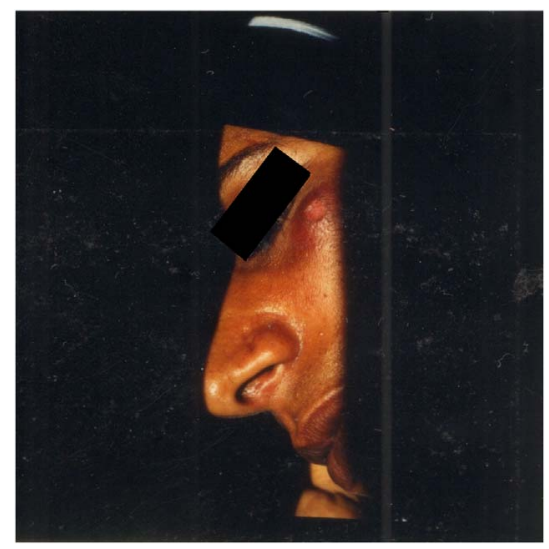

Figure 5. Ulcero-scabby lesion of case LCO 2.

and in vitro culture in NNN medium: positive. Strain MHOM/ OM/98/IBM-105-ISS1793. MLLE identification: L. tropica ZROM-102 (MDH100, ME100, ICD100, PGD95, G6PD85, GLUD100, DIA100, NP(1)450, NP(2)100, GOT(1)135, GOT (2)90, PGM100, FH100, MPI101, GPI76. The ZMON more similar was MON-39 with 4 variable isoenzymes (ME100, G6PD85, GLUD100, NP(2)100). The L. tropica species identification was confirmed by molecular analyses.

\section{Animal leishmaniases}

No Leishmania strain was isolated from canids.

\section{Discussion}

The results presented in this work were collected in 1998 and have not been published until now. However, no data related to the Sultanate of Oman have been published since this field work [5]. Dating back more than 20 years, these data remain particularly interesting in this poorly explored region regarding leishmaniases and Phlebotomine sandflies.

There are some data related to sandflies in Oman in the literature. In the 1980s, a work focusing mainly on the sandflies 
of Saudi Arabia [40] reported a batch of 14 sandflies collected around Muscat including Ph. alexandri, Se. fallax, Se. tiberiadis as well as atypical specimens possibly belonging to new taxa close to Se. christophersi and Se. schwetzi.

Our sampling showed the presence of three species of Paraphlebotomus, whereas the subgenera Larroussius, Synphlebotomus and Euphlebotomus, confirmed or putative vectors of the $L$. donovani complex, are absent. The hypothesis of their role will be discussed later.

The detail of captures by province highlights the differences between the Sharqiyah and Dhofar (Tables 2 and 3). Thus, $P h$. papatasi is observed mainly in the Sharqiyah, while $P h$. bergeroti dominates in the Dhofar. Such distribution is also observed for $P h$. saevus and $P h$. alexandri, species well represented in Dhofar and rare or absent in the Sharqiyah.

The CDC miniature light traps positioned in the villages were of little or no yield in areas with a strong anti-malarial structure applying long-life insecticides regularly. Thus, in several villages of the Sharqiyah (Batem, Hedna, Rawda) where leishmaniases have been detected, the CDC remained systematically empty, in contrast to the sticky traps positioned in the wild sites, a few kilometres away from the CDC traps. The study carried out in the Dhofar confirmed this observation.

\section{Comments on Leishmania species identification}

\section{Leishmania (Leishmania) tropica (Wright, 1903)}

The finding and isolation of L. tropica in Oman is not surprising. This parasite suspected of being responsible for CL [64], was recently isolated in Muscat from a Pakistani resident [65]. Moreover, several countries in the Middle East (Yemen, Saudi Arabia, Jordan, Syria, Iraq, Lebanon, Iran, Pakistan) and East Africa (Ethiopia, Kenya, Sudan) are known foci of L. tropica CL $[8,13,53]$. In neighbouring Yemen, there is an increasing trend of L. tropica CL [31-33]. Our results show the strain we isolated in the present study is related to Middle Eastern strains confirming the high polymorphism of L. tropica species and the description of a new variant zymodeme ROM102 (ZMON39 cluster).

The L. tropica isolation in a young girl who had never left the Dhofar region (case LCO 4, strain IBM-105) suggests the hypothetic vectorial role of Ph. saevus, the only Paraphlebotomus well represented on the site with 56 specimens caught (Tables 2 and 3), and the only member of the genus Phlebotomus, except one male of Ph. bergeroti.

\section{Leishmania (Leishmania) donovani (Laveran et Mesnil, 1903)}

The record of $L$. donovani ZMON-31 in Oman leads us to briefly discuss the taxonomic status and the geographical distribution of this zymodeme and closely related zymodemes.

Starting in the 1980s, enzymatic taxonomy studies led to consider the linnean taxa $L$. donovani and $L$. infantum as two distinct phenetic groups. Cladistic analysis confirmed these results by showing their monophyly [37, 48, 60]. In fact, these phylogenetic groups (or complex) possessed a series of synapomorphic states, such as G6PD 100, G6PD 102 G6PD 105, GPI
86, GPI 100, GOT1 100, GOT2 100, GOT 113, and GOT2 113. Some of these states were common to both branches, others only present in one of them. This was the case of PGM 100, present in the donovani-infantum set (complex synapomorphies), GOT1 100 and GOT2 100 present in the single subset $L$. infantum, and GOT1 113 and GOT2 113 present in the single subset $L$. donovani (specific synapomorphies). The taxonomic status of the donovani-infantum group changed at the end of the 1980s. Enzymatic analysis of human Leishmania strains isolated in Sudan [49, 60] and the vector $P h$. orientalis [11] showed an original zymodeme (MON-82, L. archibaldi) characterised by a heterozygous structure for GOT1 (100/113) and GOT2 (100/113), and highlighted the complexity of the systematics of $L$. donovani s. 1. [54]. Moreover, hybrids could develop differently in sandfly vectors [66].

L. donovani $\mathrm{ZMON}-31$, isolated from $\mathrm{CL}$ in Oman, was already known from Saudi Arabia [51] and Yemen [56] as responsible for VL. Moreover, this zymodeme is phylogenetically closely related to $L$. donovani $\mathrm{ZMON}-83$ (Ethiopia), ZMON-3 (Iraq), ZMON-37 (Kenya), and ZMON-2 (India), all responsible for VL. Finally, a new zymodeme, L. donovani MON-191, close to ZMON-31, was isolated from a French tourist traveling to Yemen contracting a CL [52]. Multilocus microsatellite typing (MLMT) revealed genetically isolated populations in the main endemic VL regions [35]. Leishmania donovani ZMON31 was identified within the predominantly anthroponotic $L$. donovani cluster of Sudan/Ethiopia.

Regarding the clinical aspect, even though $L$. donovani s.st. is poorly studied for tissue tropism, the complex $L$. donovani- $L$. infantum appears to cause both CL and VL.

Therefore, we consider $L$. donovani s.st. as the most probable agents of VL in Oman. However, L. infantum s. st. would be in second place, if its presence should be confirmed, as it is in Yemen (Taëz), a country where L. donovani, L. infantum and L. tropica are sympatric [57]. In Oman, the scarcity of dogs, domestic or feral, in relation to the significant number of reported human cases seems more in agreement with the circulation of $L$. donovani than that of $L$. infantum. On the basis of the sandflies collected, the proven or candidate vectors of L. donovani were not recorded: Ph. (Eup.) argentipes [34], Ph. (Lar.) orientalis, Ph. (Syn.) celiae, Ph. (Syn.) martini, or $P h$. (Ana.) rodhaini [3]. Consequently, the vector candidates for $L$. donovani transmission in the Sharqiyah region still remain unknown. For us, the only candidate could be $P h$. alexandri, a species suspected in China [27] or in Cyprus $[9,38]$, but the low densities of this species observed in Oman do not argue in favour of any role.

The low positivity rate of the skin test $(8 \%)$ reported in children of Ibra province suggests a weak interaction between the young population and the Leishmania parasite, confirming a low density of sandfly vectors or their weak anthropophilia.

Consequently, in order to better understand the epidemiology of the leishmaniases in Oman, we encourage the isolation and typing of Leishmania strains in the future, because each Leishmania complex often corresponds to a specific vector and to a particular parasitic cycle (anthroponosis/zoonosis). This was the problem previously raised when L. infantum was suspected to be the causative agent of VL in Oman [30], 
whereas $L$. donovani s.l. was later incriminated as the agent of VL [63].

\section{Conflict of interest}

None of the authors of this manuscript have a commercial or other interest that might represent a conflict.

\section{References}

1. Abonnenc E. 1972. Les phlébotomes de la région éthiopienne (Diptera, Psychodidae). Mémoires de l'ORSTOM, 55, 239 p.

2. Abonnenc E, Rioux JA. 1961. Contribution à l'étude des phlébotomes (Diptera, Psychodidae) du Nord-Tchad, in Mission épidémiologique au Nord-Tchad, Rioux JA, Editor. Arts et Métiers Graphiques: Paris. p. 30-53.

3. Al-Salem W, Herricks JR, Hotez PJ. 2016. A review of visceral leishmaniasis during the conflict in South Sudan and the consequences for East African countries. Parasites and Vectors, 9(1), 460.

4. Al-Zahrani MA, Peters W, Evans PA, Ching-Chin I, Smith V, Lane RP. 1988. Phlebotomus sergenti, a vector of Leishmania tropica in Saudi Arabia. Transactions of the Royal Society of Tropical Medicine and Hygiene, 82, 416.

5. Al Awaidy S, Al Hashami H. 2020. Zoonotic diseases in Oman: successes, challenges, and future directions. Vector Borne and Zoonotic Diseases, 20(1), 1-9.

6. Al Sineidi K, Wali YA, Pathare AV, Al Lamki Z. 2002. Visceral leishmaniasis and haemophagocytic syndrome in an Omani child. Journal for Scientific Research - Medical Sciences, 4(1-2), 45-48.

7. Alahmad G, Al-Jumah M, Dierickx K. 2012. Review of national research ethics regulations and guidelines in Middle Eastern Arab countries. BMC Medical Ethics, 13, 34.

8. Alvar J, Velez ID, Bern C, Herrero M, Desjeux P, Cano J, Jannin J, den Boer M. 2012. Leishmaniasis worldwide and global estimates of its incidence. PLoS One, 7(5), e35671.

9. Antoniou M, Haralambous C, Mazeris A, Pratlong F, Dedet JP, Soteriadou K. 2008. Leishmania donovani leishmaniasis in Cyprus. Lancet Infectious Diseases, 8(1), 6-7.

10. Artemiev M, Neronov V. 1984. Distribution and ecology of sandflies of the world (genus Phlebotomus). Ed. Sciences Ao, Moscow: Institute of Evolution Morphology and Animal Ecology, MSSR, 208 p.

11. Ashford R, Seaman J, Schorscher J, Pratlong F. 1992. Epidemic visceral leishmaniasis in southern Sudan: identity and systematic position of the parasites from patients and vectors. Transactions of the Royal Society of Tropical Medicine and Hygiene, 86, 379-380.

12. Balkhair A, Ben Abid F. 2008. Gastric and cutaneous dissemination of visceral leishmaniasis in a patient with advanced HIV. International Journal for Infectious Diseases, 12(1), 111-113.

13. Burza S, Croft SL, Boelaert M. 2018. Leishmaniasis. Lancet, 392(10151), 951-970.

14. Daoud W, Rioux JA, Delalbre-Belmonte A, Dereure J, Rageh HA. 1989. Eco-epidemiology of visceral and cutaneous leishmaniasis in the Arab Republic of Yemen. III. Inventory and dynamics of Phlebotomus. Bulletin de la Société de Pathologie Exotique, 82(5), 669-677.

15. Dedet JP, Desjeux P, Derouin F. 1982. Ecologie d'un foyer de leishmaniose cutanée dans la région de Thiès (Sénégal,
Afrique de l'Ouest). 4. - Infestation spontanée et biologie de Phlebotomus duboscqi Neveu-Lemaire 1906. Bulletin de la Société de Pathologie Exotique, 75, 588-598.

16. Depaquit J, Ferté H, Léger N, Killick-Kendrick R, Rioux JA, Killick-Kendrick M, Hanafi HA, Gobert S. 2000. Molecular systematics of the phlebotomine sandflies of the subgenus Paraphlebotomus (Diptera, Psychodidae, Phlebotomus) based on ITS2 rDNA sequences. Hypotheses Of dispersion and speciation. Insect Molecular Biology, 9(3), 293-300.

17. Depaquit J, Ferté H, Léger N, Lefranc F, Alves-Pires C, Hanafi H, Maroli M, Morillas-Marquez F, Rioux JA, Svobodova M, Volf P. 2002. ITS 2 sequences heterogeneity in Phlebotomus sergenti and Phlebotomus similis (Diptera, Psychodidae): possible consequences in their ability to transmit Leishmania tropica. International Journal for Parasitology, 32(9), $1123-1131$

18. Depaquit J, Léger N, Ferté H, Rioux JA, Gantier JC, Michaelides A, Economides P. 2001. Les phlébotomes de l'île de Chypre. III - Inventaire faunistique. Parasite, 8(1), 11-20.

19. Depaquit J, Randrianambinintsoa FJ, Jaouadi K, Payard J, Bounamous A, Augot D, Krueger A, Brengues C, Couloux A, Robert V, Leger N. 2014. Molecular and morphological systematics of the sandfly Sergentomyia (Sintonius) clydei Sinton, 1928 and questions about its record in the Seychelles. Infection Genetics and Evolution, 21, 41-53.

20. El Sawaf BM, Kassem HA, Mogalli NM, El Hossary SS, Ramadan NF. 2016. Current knowledge of sand fly fauna (Diptera: Psychodidae) of northwestern Yemen and how it relates to leishmaniasis transmission. Acta Tropica, 162, 11-19.

21. Elnour IB, Akinbami FO, Shakeel A, Venugopalan P. 2001. Visceral leishmaniasis in Omani children: a review. Annals of Tropical Paediatrics International Child Health, 21(2), 159-163.

22. Fathalla M, Hashim J, Alkindy H, Wali Y. 2007. Cerebrospinal fluid involvement in a case of visceral leishmaniasis associated with hemophagocytic lymphohistiocytosis. Sultan Qaboos University Medical Journal, 7(3), 253-256.

23. Gaifer Z, Boulassel MR. 2016. Leishmania infantum and Epstein-Barr virus co-infection in a patient with hemophagocytosis. Infectious Disease Reports, 8(4), 6545.

24. Galati EAB, Galvis-Ovallos F, Lawyer P, Léger N, Depaquit J. 2017. An illustrated guide for characters and terminology used in descriptions of Phlebotominae (Diptera, Psychodidae). Parasite, $24,26$.

25. George L, Gunwardana S. 1994. Visceral leishmaniasis in the Dhofar region of Oman. Oman Medical Journal, 11, 5-6.

26. Ghasanfar S. 1992. Quantitative and biogeographic analysis of the flora of the Sultanat of Oman. Global Ecology \& Biogeography Letters, 2, 189-195.

27. Guan LR, Xu YX, Li BS, Dong J. 1986. The role of Phlebotomus alexandri Sinton, 1928 in the transmission of kala-azar. Bulletin of the World Health Organisation, 64, 107-112.

28. Guilvard E, Rioux JA, Gallego M, Pratlong F, Mahjour J, Martinez-Ortega E, Dereure J, Saddiki A, Martini A. 1991. Leishmania tropica au Maroc. III. Rôle vecteur de Phlebotomus sergenti. Annales de Parasitologie Humaine et Comparée, 66(3), 96-99.

29. Houin R, Léger N, Dupouy-Camet J, Bastien P, Luffau G. 2018. In memoriam Professor Jean-Antoine Rioux (19252017). Parasite, 25, 13.

30. John K. 1986. Kala-azar in Oman. Medical Newsletter of Oman, 3, 22-30.

31. Khatri ML, Di Muccio T, Fiorentino E, Gramiccia M. 2016. Ongoing outbreak of cutaneous leishmaniasis in northwestern Yemen: clinicoepidemiologic, geographic, and taxonomic study. International Journal of Dermatology, 55(11), 1210-1218. 
32. Khatri ML, Di Muccio T, Gramiccia M. 2009. Cutaneous leishmaniasis in North-Western Yemen: A clinicoepidemiologic study and Leishmania species identification by polymerase chain reaction-restriction fragment length polymorphism analysis. Journal of the American Academy of Dermatology, 61(4), e15-21.

33. Khatri ML, Haider N, Di Muccio T, Gramiccia M. 2006. Cutaneous leishmaniasis in Yemen: clinicoepidemiologic features and a preliminary report on species identification. International Journal of Dermatology, 45(1), 40-45.

34. Killick-Kendrick R. 1990. Phlebotomine vectors of the leishmaniases: A review. Medical and Veterinary Entomology, 4, 1-24.

35. Kuhls K, Keilonat L, Ochsenreither S, Schaar M, Schweynoch C, Presber W, Schonian G. 2007. Multilocus microsatellite typing (MLMT) reveals genetically isolated populations between and within the main endemic regions of visceral leishmaniasis. Microbes and Infection, 9(3), 334-343.

36. Lane RP, Büttiker W. 1988. Sandflies (Diptera : Phlebotominae) from the Wahiba Sands, Oman. Journal of Oman Studies Special Report, 3, 389-390.

37. Lanotte G, Rioux J, Lepart J, Maazoun R, Pasteur N, Pratlong F. 1984. Contribution de la cladistique numérique à la phylétique du genre Leishmania Ross, 1903 (KinetoplastidaTrypanosomatidae). Utilisation des caractères enzymatiques. Comptes Rendus de l'Académie des Sciences, Série III,, 299 (19), 769-772.

38. Léger N, Depaquit J. 2008. Leishmania donovani leishmaniasis in Cyprus. Lancet Infectious Diseases, 8(7), 402.

39. Lewis D. 1982. A taxonomic review of the genus Phlebotomus. Bulletin of the British Museum (Natural History), Entomology Series, 45, 121-209.

40. Lewis D, Büttiker W. 1980. Insects of Saudi Arabia. Diptera : fam. Psychodidae, subfam. Phlebotominae. Fauna of Saudi Arabia, 2, 252-285.

41. Lewis DJ. 1978. The phlebotomine sandflies (Diptera: Psychodidae) of the Oriental Region. Bulletin of the British Museum (Natural History), Entomology Series, 37(6), 217-343.

42. Lewis DJ, Bûttiker W. 1982. Insects of Saudi Arabia. The taxonomy and distribution of Saudi Arabian Phlebotomine sandflies (Diptera, Psychodidae). Fauna of Saudi Arabia, 4, 353-397.

43. Lewis DJ, Bûttiker W. 1986. Some Phlebotomine sandflies (Diptera : Psychodidae) from Saudi Arabia. Fauna of Saudi Arabia, 8, 324-339.

44. Martin R. 1938. Observations sur les Phlébotomes d'Éthiopie. Archives de l'Institt Pasteur d'Algérie, 16, 219-225.

45. Mebrahtu Y, Lawyer P, Githure J, Kager P, Leeuwenburg J, Perkins P, Oster C, Hendricks LD. 1988. Indigenous human cutaneous leishmaniasis caused by Leishmania tropica in Kenya. American Journal of Tropical Medicine and Hygiene, 39(3), 267-273.

46. Miller A, Morris M. 1988. Plants of Dhofar. The Southern Region of Oman. Traditional, Economic and Medical Uses. Muscat: Office of the Adviser for Conservation of the Environment, Diwan of Royal Court. 390 p.

47. Moin-Vaziri V, Depaquit J, Yaghoobi-Ershadi MR, Oshaghi MA, Derakhshandeh-Peykar P, Ferté H, Kaltenbach M, Bargues MD, Léger N, Nadim A. 2007. Intraspecific variation within Phlebotomus sergenti Parrot (1917) (Diptera: Psychodidae) based on mtDNA sequences in Islamic Republic of Iran. Acta Tropica, 102(1), 29-37.

48. Moreno G, Rioux JA, Lanotte G, Pratlong F, Serres S. 1984. Le complexe Leishmania donovani s.l. Analyse enzymatique et traitement numérique. Individualisation du complexe
Leishmania infantum. Corollaires biogéographiques et phylétiques. A propos de 146 souches originaires de l'Ancien et du Nouveau Monde, in Leishmania. Taxonomie et phylogénèse (Coll. int. CNRS/INSERM), Rioux JA, Editor. IMEEE: Montpellier. p. 105-117.

49. Oskam L, Pratlong F, Zijlstra E, Kroon C, Dedet J, Kager P, Schönian G, Ghalib H, El-Hassan A, Meredith S. 1998. Biochemical and molecular characterization of Leishmania parasites isolated from an endemic focus in eastern Sudan. Transactions of the Royal Society of Tropical Medicine and Hygiene, 92, 120-122.

50. Padmanabhan A, Nair R. 1995. Leishmaniasis in North Sharqiya region. Oman Medical Journal, 12, 11-12.

51. Peters W, Elbihari S, Liu C, Le Blancq S, Evans D, KillickKendrick R, Smith V, Baldwin C. 1985. Leishmania infecting man and wild animals in Saudi Arabia. 1. General survey. Transactions of the Royal Society of Tropical Medicine and Hygiene, 79, 831-839.

52. Pratlong F, Bastien P, Perello R, Lami P, Dedet JP. 1995. Human cutaneous leishmaniasis caused by Leishmania donovani sensu stricto in Yemen. Transactions of the Royal Society of Tropical Medicine and Hygiene, 89(4), 398-399.

53. Pratlong F, Dereure J, Ravel C, Lami P, Balard Y, Serres G, Lanotte G, Rioux JA, Dedet JP. 2009. Geographical distribution and epidemiological features of Old World cutaneous leishmaniasis foci, based on the isoenzyme analysis of 1048 strains. Tropical Medicine and International Health, 14, 1071-1085.

54. Pratlong F, Lami P, Ravel C, Balard Y, Dereure J, Serres G, Baidouri FE, Dedet JP. 2013. Geographical distribution and epidemiological features of Old World Leishmania infantum and Leishmania donovani foci, based on the isoenzyme analysis of 2277 strains. Parasitology, 140(4), 423-434.

55. Randrianambinintsoa FJ, Léger N, Robert V, Depaquit J. 2014. Paraphyly of the subgenus Sintonius (Diptera, Psychodidae, Sergentomyia): status of the Malagasy species. Creation of a new subgenus and description of a new species. PLoS One, 9(6), e98065.

56. Rioux J, Daoud W, Pratlong F, El KubatiI Y, Moreno G, Rageh H, Brun R, Mouharem A, Martinez-Ortega E, Belmonte A. 1986. Les complexes Leishmania donovani s. st., Leishmania tropica et Leishmania major en République Arabe du Yémen. Considérations taxonomiques et épidémiologiques, in Leishmania. Taxonomie et phylogénèse (Coll. int. CNRS/INSERM, 1984), Rioux JA, Editor. IMEEE: Montpellier. p. 357-363.

57. Rioux J, Dereure J, Daoud W, El KubatiI Y, Rageh HA, Moreno G, Pratlong F. 1989. Ecoépidémiologie des leishmanioses viscérales et cutanées en République Arabe du Yémen. I. Présence en condition sympatrique, des complexes Leishmania infantum et Leishmania donovani. Bulletin de la Société de Pathologie Exotique, 82, 658-664.

58. Rioux JA, Golvan YJ. 1969. Epidémiologie des leishmanioses dans le sud de la France. Paris: Institut National de la santé et de la Recherche Médicale. 223 P.

59. Rioux JA, Carron S, Dereure J, Perieres J, Zeraia L, Franquet E, Babinot M, Gallego M, Prudhomme J. 2013. Ecology of leishmaniasis in the South of France. 22. Reliability and representativeness of 12 Phlebotomus ariasi, P. perniciosus and Sergentomyia minuta (Diptera: Psychodidae) sampling stations in Vallespir (eastern French Pyrenées region). Parasite, 20,34 .

60. Rioux JA, Lanotte G, Serres E, Pratlong F, Bastien P, Périères J. 1990. Taxonomy of Leishmania. Use of isoenzymes. Suggestions for a new classification. Annales de Parasitologie Humaine et Comparée, 65(3), 111-125. 
61. Roberts D, Kumar S. 1994. Using vehicle-mounted nets for studying activity of Arabian sand flies (Diptera : Psychodidae). Journal of Medical Entomology, 31(3), 388-393.

62. Schonian G, Nasereddin A, Dinse N, Schweynoch C, Schallig HD, Presber W, Jaffe CL. 2003. PCR diagnosis and characterization of Leishmania in local and imported clinical samples. Diagnostic Microbiology and Infectious Disease, 47(1), 349-358.

63. Scrimgeour EM, Barker DC, Al-Waily A, Idris M, Lambson B, Nirmala V, Windsor JJ. 1998. First identification of a species of Leishmania causing visceral leishmaniasis in the Sultanate of Oman, in a patient with AIDS. Transactions of the Royal Society of Tropical Medicine and Hygiene, 92(3), 356-357.

64. Scrimgeour EM, Mehta FR, Suleiman AJ. 1999. Infectious and tropical diseases in Oman: a review. American Journal of Tropical Medicine and Hygiene, 61(6), 920-925.

65. Scrimgeour EM, Windsor JJ, Shetty MK, Banodkar DD, Lambson B, Barker DC, Idris MA, McCann SH, Al-Suwaid AR. 1999. Leishmania tropica is a probable cause of cutaneous leishmaniasis in the Sultanate of Oman: Case report in a Pakistani resident. Transactions of the Royal Society of Tropical Medicine and Hygiene, 93(3), 233-234.

66. Seblova V, Myskova J, Hlavacova J, Votypka J, Antoniou M, Volf P. 2015. Natural hybrid of Leishmania infantum/L. donovani: Development in Phlebotomus tobbi, P. perniciosus and Lutzomyia longipalpis and comparison with non-hybrid strains differing in tissue tropism. Parasites \& Vectors, 8, 605.
67. Seccombe AK, Ready PD, Huddleston LM. 1993. A catalogue of Old World phlebotomine sandflies (Diptera, Phlebotominae). Occasional Papers on Systematic Entomology, 8, 1-57.

68. Senghor MW, Niang AA, Depaquit J, Ferte H, Faye MN, Elguero E, Gaye O, Alten B, Perktas U, Cassan C, Faye B, Bañuls AL. 2016. Transmission of Leishmania infantum in the Canine Leishmaniasis Focus of Mont-Rolland, Senegal: Ecological, Parasitological and Molecular Evidence for a Possible Role of Sergentomyia Sand Flies. PLoS Neglected Tropical Diseases, 10(11), e0004940.

69. Tateng AN, Payne VK, Ngouateu OB, Kirstein OD, Warburg A, von Stebut E, Maurer M, Dondji B, Kruger A. 2019. Inventory and taxonomy of phlebotomine sand flies of the Mokolo leishmaniasis focus, northern Cameroon, with description of new Sergentomyia taxa (Diptera: Psychodidae). Acta Tropica, 194, 172-180.

70. Van der Auwera G, Bart A, Chicharro C, Cortes S, Davidsson L, Di Muccio T, Dujardin JC, Felger I, Paglia MG, Grimm F, Harms G, Jaffe CL, Manser M, Ravel C, Robert-Gangneux F, Roelfsema J, Toz S, Verweij JJ, Chiodini PL. 2016. Comparison of Leishmania typing results obtained from 16 European clinical laboratories in 2014. Euro Surveillance, 21, 49.

71. Venkataram M, Moosa M, Devi L. 2001. Histopathological spectrum in cutaneous leishmaniasis: A study in Oman. Indian Journal of Dermatology, Venereology and Leprology, 67(6), 294-298.

Cite this article as: Rioux J-A, Gramiccia M, Léger N, Desjeux P \& Depaquit J. 2020. Leishmaniasis and phlebotomine sand flies in Oman Sultanate. Parasite 27, 68.

O PARASTE

An international open-access, peer-reviewed, online journal publishing high quality papers on all aspects of human and animal parasitology

Reviews, articles and short notes may be submitted. Fields include, but are not limited to: general, medical and veterinary parasitology; morphology, including ultrastructure; parasite systematics, including entomology, acarology, helminthology and protistology, and molecular analyses; molecular biology and biochemistry; immunology of parasitic diseases; host-parasite relationships; ecology and life history of parasites; epidemiology; therapeutics; new diagnostic tools.

All papers in Parasite are published in English. Manuscripts should have a broad interest and must not have been published or submitted elsewhere. No limit is imposed on the length of manuscripts.

Parasite (open-access) continues Parasite (print and online editions, 1994-2012) and Annales de Parasitologie Humaine et Comparée (1923-1993) and is the official journal of the Société Française de Parasitologie.
Submit your manuscript at http://parasite.edmgr.com/ 